\title{
Effect of Anolyte pH on the Performance of a Dual-Chambered Microbial Fuel Cell Operated with Different Biomass Feed
}

\author{
Md. Abdul Halim, Md. Owaleur Rahman, Mohammad Ibrahim, Rituparna Kundu, \\ and Biplob Kumar Biswas $\mathbb{D}$ \\ Department of Chemical Engineering, Jashore University of Science and Technology, Jashore-7408, Bangladesh \\ Correspondence should be addressed to Biplob Kumar Biswas; bk.biswas@just.edu.bd
}

Received 29 June 2021; Revised 10 August 2021; Accepted 17 August 2021; Published 26 August 2021

Academic Editor: M. N. Mohamad Ibrahim

Copyright (C) $2021 \mathrm{Md}$. Abdul Halim et al. This is an open access article distributed under the Creative Commons Attribution License, which permits unrestricted use, distribution, and reproduction in any medium, provided the original work is properly cited.

Finding sustainable alternative energy resources and treating wastewater are the two most important issues that need to be solved. Microbial fuel cell (MFC) technology has demonstrated a tremendous potential in bioelectricity generation with wastewater treatment. Since wastewater can be used as a source of electrolyte for the MFC, the salient point of this study was to investigate the effect of $\mathrm{pH}$ on bioelectricity production using various biomass feed (wastewater and river water) as the anolyte in a dualchambered MFC. Maximum extents of power density $\left(1459.02 \mathrm{~mW} \cdot \mathrm{m}^{-2}\right)$, current density $\left(1288.9 \mathrm{~mA} \cdot \mathrm{m}^{-2}\right)$, and voltage $(1132 \mathrm{mV})$ were obtained at $\mathrm{pH} 8$ by using Bhairab river water as a feedstock in the MFC. A substantial extent of chemical oxygen demand (COD) removal (94\%) as well as coulombic efficiency $(41.7 \%)$ was also achieved in the same chamber at $\mathrm{pH} 8$. The overall performance of the MFC, in terms of bioelectricity generation, COD removal, and coulombic efficiency, indicates a plausible utilization of the MFC for wastewater treatment as well as bioelectricity production.

\section{Introduction}

In recent years, utilization of energy in the whole world increased enormously due to the rising of the global population, industrialization, and urbanization. Energy comes from various sources, which include renewable and nonrenewable sources. All nonrenewable energy resources (e.g., fossil fuel) have a negative impact on the environment, and thus, the fossil fuels are no more considered as an ideal energy source [1]. Moreover, the excessive use of fossil fuel leads to its depletion at a rapid pace. Therefore, to meet the demand of energy, it is of utmost necessity to find clean, reliable, and sustainable energy resources. Energy crisis and environmental pollution are two major issues that need to be addressed. In this regard, production and utilization of alternative energy sources are of great interest due to their benign impact on the environment. To solve this problem, microbial fuel cell (MFC) is supposed to be a promising technology because it not only generates renewable energy but also helps bioremediation of water pollutants. Microbial fuel cell, an eco-friendly and low-cost device, produces energy (electricity) by decomposing carbon-based substances existing in the anolyte. Thus, MFC's technique helps in treating wastewater of different genres. Various wastewater and industrial effluents can be used as electrolytes in the MFC. Since effluents and wastewater are causing environmental pollution very much, their treatment is required indeed to improve the environmental condition from pollution. Apart from the classical wastewater treatment and management techniques, MFC generates bioelectricity as well [2]. However, collective knowledge of engineering, biology, and chemistry is required for the assembly and operation of microbial fuel cells [3].

Microbial fuel cells basically consist of two chambers, which are called the anode chamber and cathode chamber. Both chambers hold the electrode and are separated by a permeable membrane [4]. The three most important key materials of MFCs are the electrode, membrane, and electrolyte, which determine the performance of the MFCs. Various organic wastewater can be used as electrolytes in MFCs because organic wastewater can supply energy for bacteria to enhance the electrochemical reaction. In this study, municipal 
wastewater, Bhairab river water, and hospital wastewater were used as electrolytes for the MFC. In the anode chamber, the respiratory bacteria oxidize the organic substrate in wastewater to produce electrons and protons. The electrons are then transferred to the cathode chamber through an electric circuit, while the protons pass through the permeable membrane towards the cathode chamber and react with oxygen to form water. However, better yield optimization and improvement of the electrode of the MFC are still thought-provoking research topics worldwide [5]. Ion exchange membrane, particularly cation exchange membrane (CEM), is very effective on a large scale with greater depth of the electrolyte. Though the MFC can treat numerous cations (e.g., $\mathrm{Na}^{+}, \mathrm{Ca}^{2+}, \mathrm{K}^{+}$, and $\mathrm{NH}_{4}^{+}$) present in the electrolyte (wastewater), this is contested by protons that attribute to the negatively charged functional groups in the CEM [6]. This can reduce the extent of bioenergy generation. Bacteria can help increase the output of the MFC and reject the mediator from the anode chamber. The literature reveals that electrolytes such as dairy wastewater, tannery wastewater, landfill leachate, and poultry dropping wastewater have been used in MFCs in the view to treat wastewater and to generate electricity simultaneously [7-10]. Although MFCs have been investigated for bioelectricity generation from the aforementioned wastewater, no study has been reported on microbial fuel cell operation using Bhairab river water, hospital wastewater, and municipal wastewater of Jashore, Bangladesh. Beside wastewater, MFC can use clean mixtures such as acetate or butyrate, alcohol, fatty acid, monosaccharide sugar, sucrose, and glucose as the electrolyte $[11,12]$. To improve the performance of the microbial fuel cell, recently, researchers performed several studies on it by using the membrane, mediators in salt bridge, and biocathodes [13-15]. Various operating parameters such as $\mathrm{pH}$, anode, and cathode ingredients, the space among the electrodes, external resistance, temperature, and conductivity are reported to affect the generated outputs from the microbial fuel cell [16].

Even though the MFC has already become an emerging research field, there are still scopes for its development that include cost minimization, design modification, $\mathrm{pH}$ optimization, power output, and wastewater treatment. Therefore, more research work should be conducted to focus on mitigating these issues. In this regard, the current study focused on preparing a low-cost and easy-to-construct dualchambered microbial fuel cell by using locally available materials and to examine different types of biomass feed (wastewater and river water) for their utility as anolytes in the MFC. Municipal wastewater, hospital wastewater, and Bhairab river water were collected locally and used as electrolytes in the anodic chamber. This study also investigated $\mathrm{pH}$ optimization because $\mathrm{pH}$ is considered to be a very important parameter, which affects the efficiency of the MFC. In addition, power output, COD removal, and coulombic efficiencies were examined as well.

\section{Materials and Methods}

2.1. Materials' Collection and Cell Construction. In the current study, a double-chamber MFC was constructed. The materials used to construct the MFC were purchased from the local markets of Jashore, Bangladesh. A double-chamber MFC consists of two chambers such as the (i) anode chamber where an anode is placed and (ii) cathode chamber where a cathode is placed. Both chambers are connected by a salt bridge, which allows protons to transfer from the anode chamber to the cathode chamber. Anode chamber is filled with targeted wastewater, while the cathode chamber is filled with tap water. The anode and cathode were connected with an epoxy-coated copper wire, and the circuit was completed by using a resistor [10]. Zinc and copper plate was used as the anode and cathode, respectively. The surface area of each plate was $0.0027 \mathrm{~m}^{2}$. The chambers were fabricated by using locally available glass sheet. The length, width, and height of each chamber were $0.25 \mathrm{~m}, 0.10 \mathrm{~m}$, and $0.20 \mathrm{~m}$, respectively. An agar salt bridge was used to connect the chambers. For making the salt bridge, pieces of surgical cloth were soaked in $0.1 \mathrm{M}$ agar solution for about $2-3 \mathrm{~h}$. After soaking, the pieces of surgical cloth were inserted in a PVC pipe with a diameter and length of $0.5 \mathrm{~cm}$ and $4.0 \mathrm{~cm}$, respectively. All joints of the MFC were sealed using M-seal (K1 Mart, India) to prevent any leakage [17]. A schematic presentation and experimental setup of a double-chamber MFC are shown in Figure 1.

\subsection{Microbe Inoculation and Anolyte Collection. Several} microorganisms such as Escherichia coli, Anabaena, Rhodospirillum, and some cyanobacteria were used in all experiments. At first, organic rich bottom feeders were collected from the local pond, which were then cultured for proper growth of microorganisms. It was done by mixing $1.5 \%(\mathrm{w} / \mathrm{w})$ cow dung and $0.2 \%(\mathrm{w} / \mathrm{w})$ sugar with bottom feeders. The mixture was kept in an anaerobic condition for $48 \mathrm{~h}$. After inoculation, these microbes were added in the anode chamber for the experiment. The untreated raw wastewater (collected from the municipal drain of Jashore town, Bangladesh, from the Bhairab River flowing over Jashore district, Bangladesh, and from Jashore General Hospital, Bangladesh) was used in the anode chamber. Municipal wastewater was collected from a municipal drain where the flow rate was $225 \mathrm{~mL} \cdot \mathrm{s}^{-1}$, while water from the Bhairab River was collected at $150 \mathrm{~cm}$ beneath the surface. Figure 2 shows the location of two sources of wastewater. However, wastewater from the hospital was collected from a pipeline where the flow rate was measured to be $195 \mathrm{~mL} \cdot \mathrm{s}^{-1}$. The average chemical compositions of these samples are tabulated in Table 1 . The average COD of raw municipal wastewater, Bhairab river water, and hospital wastewater was determined to be $784 \mathrm{mg} \cdot \mathrm{L}^{-1}, 832 \mathrm{mg} \cdot \mathrm{L}^{-1}$, and $842 \mathrm{mg} \cdot \mathrm{L}^{-1}$, respectively.

2.3. Collection of Data and Their Analysis. To assess the electrochemical characterization of the MFC, data in terms of voltage and current were recorded on a daily basis (from 10:00 AM to 4:40 PM) by using a digital multimeter (DT$9205 \mathrm{~A}$, China) at a fixed interval of $20 \mathrm{~min}$. The mean value was determined each day and was plotted to obtain necessary figures. After obtaining the extent of voltage and current, 


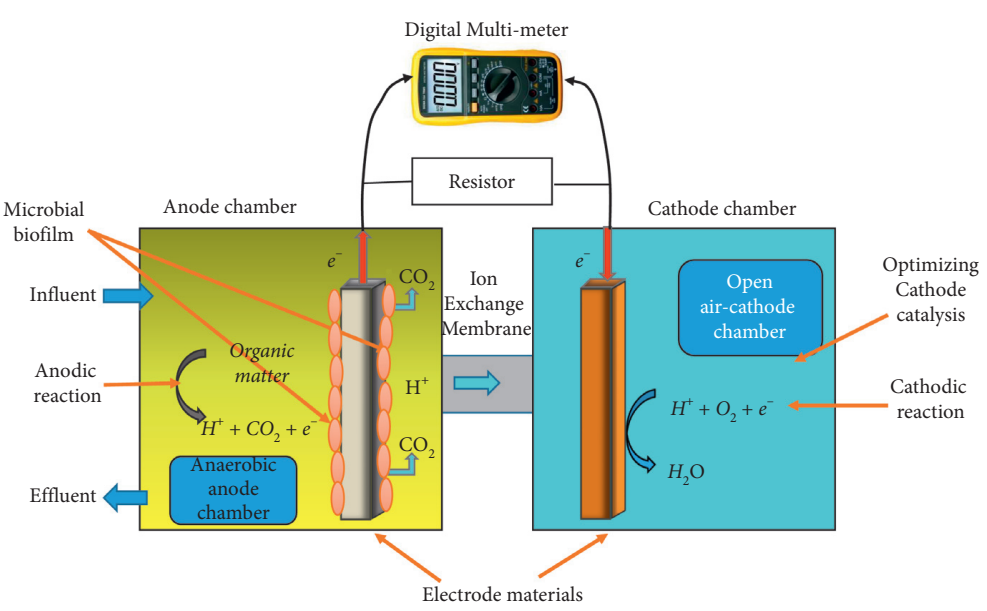

(a)

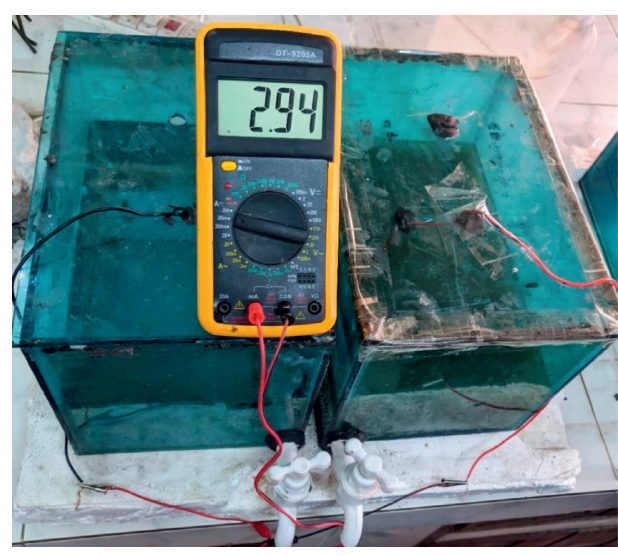

(b)

Figure 1: (a) Schematic presentation and (b) experimental setup of the double-chamber MFC.

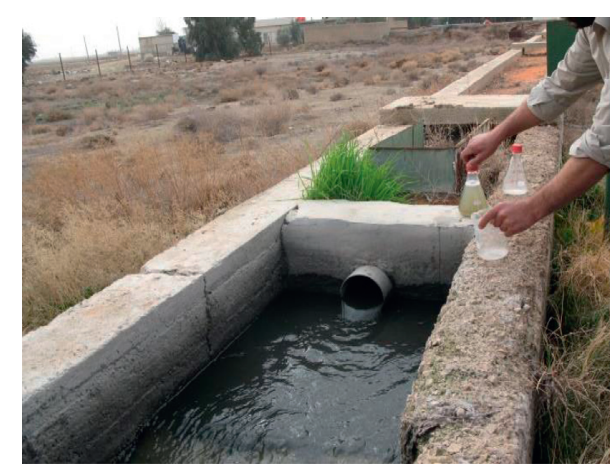

(a)

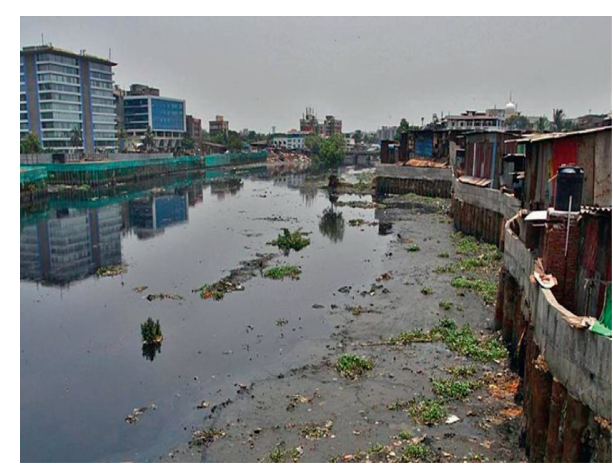

(b)

FIgURE 2: Sources of wastewater used as electrolytes: (a) municipal drain; (b) Bhairab River.

power density $\left(P_{\text {anode }}, \mathrm{W} \cdot \mathrm{m}^{-2}\right)$ and current density $\left(I_{\text {anode, }}\right.$, $\mathrm{A} \cdot \mathrm{m}^{-2}$ ) were determined by using the following equations:

$$
\begin{gathered}
P_{\text {anode }}=\frac{P}{A}, \\
I_{\text {anode }}=\frac{I}{A},
\end{gathered}
$$

where $I$ is the current (A), $P$ is the power (W), and $A$ is the external area $\left(\mathrm{m}^{2}\right)$ of the anode.

2.4. Calculation of COD Removal. Chemical oxygen demand (COD) specifies the quantity of oxygen $\left(\mathrm{O}_{2}\right)$ that can be consumed by reactions in a measured solution. The carbonbased substance existing in the water sample is dissolved by potassium dichromate $\left(\mathrm{K}_{2} \mathrm{Cr}_{2} \mathrm{O}_{7}\right)$ in the presence of sulfuric acid $\left(\mathrm{H}_{2} \mathrm{SO}_{4}\right)$, silver sulfate $\left(\mathrm{Ag}_{2} \mathrm{SO}_{4}\right)$, and mercury sulfate $\left(\mathrm{HgSO}_{4}\right)$ to harvest carbon dioxide $\left(\mathrm{CO}_{2}\right)$ and water $\left(\mathrm{H}_{2} \mathrm{O}\right)$. $\mathrm{COD}$ can be calculated by using the following equation:

$$
\mathrm{COD}=\frac{8 \times 1000 \times \mathrm{DF} \times M \times\left(V_{B}-V_{S}\right)}{V_{\text {sample }}}
$$

where DF stands for the dilution factor, $M$ stands for the molarity of standardized ferrous ammonium sulfate $\left(\left(\mathrm{NH}_{4}\right)_{2} \mathrm{Fe}\left(\mathrm{SO}_{4}\right)_{2} \cdot 6 \mathrm{H}_{2} \mathrm{O}\right)$ solution, $V_{B}$ stands for the volume used up in titration through blank preparation, $V_{S}$ stands for the volume used up in titration through sample preparation, and $V_{\text {sample }}$ denotes the volume of the sample.

The removal percentage of COD was calculated by using the following equation:

$$
\operatorname{COD} \operatorname{removal}(\%)=\frac{\mathrm{COD}_{\text {in }}-\mathrm{COD}_{\text {out }}}{\mathrm{COD}_{\text {in }}} \times 100,
$$

where $\mathrm{COD}_{\text {in }}\left(\mathrm{g} \cdot \mathrm{L}^{-1}\right)$ is the influent concentration and $\mathrm{COD}_{\text {out }}\left(\mathrm{g} \cdot \mathrm{L}^{-1}\right)$ is the concentration after treatment.

2.5. Calculation of Coulombic Efficiency (CE). While the basic function of a MFC is to generate power, it is necessary to extract electrons from the electrolyte and thus to recover energy as much as possible from the system. The extraction or recovery of electrons from the electrolyte is referred to as coulombic efficiency, which can be defined as the percentage of total charge transferred to the anode surface over the maximum charge extractable upon complete oxidation of 
TABLE 1: The chemical composition of various biomass feed.

\begin{tabular}{lcccc}
\hline Parameter & Municipal wastewater $\left(\mathrm{mg} \cdot \mathrm{L}^{-1}\right)$ & Bhairab river water $\left(\mathrm{mg} \cdot \mathrm{L}^{-1}\right)$ & Hospital wastewater $\left(\mathrm{mg} \cdot \mathrm{L}^{-1}\right)$ & Used technique \\
\hline $\mathrm{HCO}_{3}^{-}$ & 347.4 & 354.8 & 294.6 & Ion chromatography \\
$\mathrm{Cl}^{-}$ & 395.8 & 565.6 & 835.3 & Titrimetry \\
$\mathrm{Ca}^{2+}$ & 32.4 & 38.6 & 56.6 & Titrimetry \\
$\mathrm{Mg}^{2+}$ & 26.7 & 32.3 & 18.7 & Titrimetry \\
$\mathrm{Na}^{+}$ & 17.3 & 21.9 & 19.9 & Flame photometry \\
$\mathrm{NO}_{3}^{-}$ & 4.42 & 3.24 & 13.18 & Spectrophotometry \\
$\mathrm{SO}_{4}^{2-}$ & 82.3 & 87.5 & 127.5 & Ion chromatography \\
$\mathrm{PO}_{4}^{2-}$ & 6.25 & 5.8 & 3.9 & Ion chromatography \\
\hline
\end{tabular}

the substrate in the electrolyte. The CE is an important measure of the efficiency of a microbial fuel cell as it measures the number of coulombs recovered as electrical current. Two major factors affect the CE of any microbial fuel cell: firstly, the microorganism carrying out the electrochemical reaction and secondly, the substrate used by the bacteria to generate current. CE can be calculated by using the following equation [18]:

$$
\mathrm{CE}(\%)=\frac{8 \int I \cdot \mathrm{d} t}{F \cdot V_{\mathrm{An}} \cdot \Delta \mathrm{COD}} \times 100,
$$

where $I(\mathrm{~A})$ is the current, $F$ is Faraday's constant (96485 C/ mole), $V_{\text {An }}(\mathrm{L})$ is the volume of treated wastewater, and $\triangle \mathrm{COD}\left(\mathrm{g} \cdot \mathrm{L}^{-1}\right)$ is the difference between $\mathrm{COD}_{\text {in }}$ and $\mathrm{COD}_{\text {out }}$.

\section{Results and Discussion}

Parameters such as $\mathrm{pH}$, electrode constituents, the space between the electrodes, external resistance, temperature, conductivity, and biological matter of the residue are reported to affect the electricity generation of the microbial fuel cell [19-21]. The performance of the MFC increased for long-term operation when the electrogenic biofilm formed on the electrode surface. $\mathrm{pH}$ of electrolytes is supposed to be a crucial parameter in assessing the performance of a microbial fuel cell, particularly from the viewpoint of the power output [22]. In this study, $\mathrm{pH}$ of feedstock (anolyte) was varied from 6 to 10, and the MFC output (voltage, current density, power density, etc.) was meticulously analyzed.

\subsection{Effect of $p H$ Using Municipal Wastewater as the Electrolyte.} Since $\mathrm{pH}$ is a key parameter that affects the generation of bioelectricity in the MFC, it is necessary to figure out the effect of $\mathrm{pH}$ using municipal wastewater as an electrolyte. A series of experiments were conducted by varying $\mathrm{pH}$ (from $\mathrm{pH} 6$ to $\mathrm{pH} \mathrm{10)}$ of the electrolyte, while the other parameters such as operating temperature, volume of the electrolyte, materials of electrodes, and surface area of electrodes were kept constant. The data (current and voltage) were recorded and analyzed to calculate power density and current density. The results are depicted in Figures 3(a)-3(c). The effect of $\mathrm{pH}$ on voltage for an experimental period of 1-15 days is shown in Figure 3(a). It was obvious that $\mathrm{pH} 8$ gave the highest output (in the form of voltage) all through the experimental period compared to other experimented $\mathrm{pH}$ values. The voltage gradually increased up to day 4 , and then it started to decrease. The highest value of voltage $(1125 \mathrm{mV})$ was obtained at day 4 for the process operated at $\mathrm{pH} 8$.

On the contrary, current density increases up to day 3 for all tested $\mathrm{pH}$ values as shown in Figure 3(b). Then, it starts decreasing gradually. However, the maximum value of current density was found to be $1155.6 \mathrm{~mA} \cdot \mathrm{m}^{-2}$ for $\mathrm{pH} 8$ at day 3. Like voltage and current density, the highest power density was obtained at $\mathrm{pH} 8$ which was $1245.7 \mathrm{~mW} \cdot \mathrm{m}^{-2}$, while for $\mathrm{pH} 6,7,9$, and 10 , the maximum power density was determined to be $1008.7,1066.8,990.9$, and $837.8 \mathrm{~mW} \cdot \mathrm{m}^{-2}$, respectively (as shown in Figure 3(c)). It is obvious from Figures 3(a)-3(c) that voltage, current density, and power density increase for first several days and then start to decrease gradually. The increase in the extent of current density, voltage, and power density in initial days occurs due to inoculation of microorganisms in the electrolyte [23]. In this experiment, it takes three to four days for complete inoculation of bacteria. However, the decrease in the extent of power density may occur owing to the fact that extracellular polymeric substance (ESP) content may be accumulated in the biofilm with time [24]. However, Omprakash reported the maximum current and power density of $23.66 \mathrm{~mA}$ and $5.1 \mathrm{~mW} \cdot \mathrm{m}^{-2}$, respectively, by using carbon paper and magnesium oxide as electrodes and sugar industrial wastewater as the electrolyte at $\mathrm{pH} 6.9$ [25]. Therefore, the findings in this study (in terms of voltage, current density, and power density) were much better.

The COD removal and CE are the two important parameters for the microbial fuel cell because productivity of the MFC largely depends on these two parameters [26]. The initial COD of municipal wastewater in Jashore, Bangladesh, was $538 \mathrm{mg} \cdot \mathrm{L}^{-1}$. In this experiment, the COD removal was observed to be over $86 \%, 89 \%, 91 \%, 88 \%$, and $86 \%$ at initial $\mathrm{pH}$ of $6,7,8,9$, and 10 , respectively. At the same time, the CE was determined as $28.4 \%, 33.6 \%, 38.8 \%, 32.7 \%$, and $25.9 \%$ at initial $\mathrm{pH} 6,7,8,9$, and 10 , respectively.

\subsection{Effect of $p H$ Using Bhairab River Water as the Electrolyte.} As mentioned earlier, water of the Bhairab River was used as the electrolyte in MFC operation. In pursuit of optimum operating $\mathrm{pH}$, experiments were conducted by varying $\mathrm{pH}$ of the electrolyte, keeping all other parameters constant. The experiments were conducted for 15 days as depicted in Figures $4(\mathrm{a})-4(\mathrm{c})$. The effect of $\mathrm{pH}$ on voltage generation is shown in Figure 4(a) where it is obvious that, for all experimented $\mathrm{pH}$ values, the voltage gradually increases up to day 4 and then starts to decrease. The maximum output 


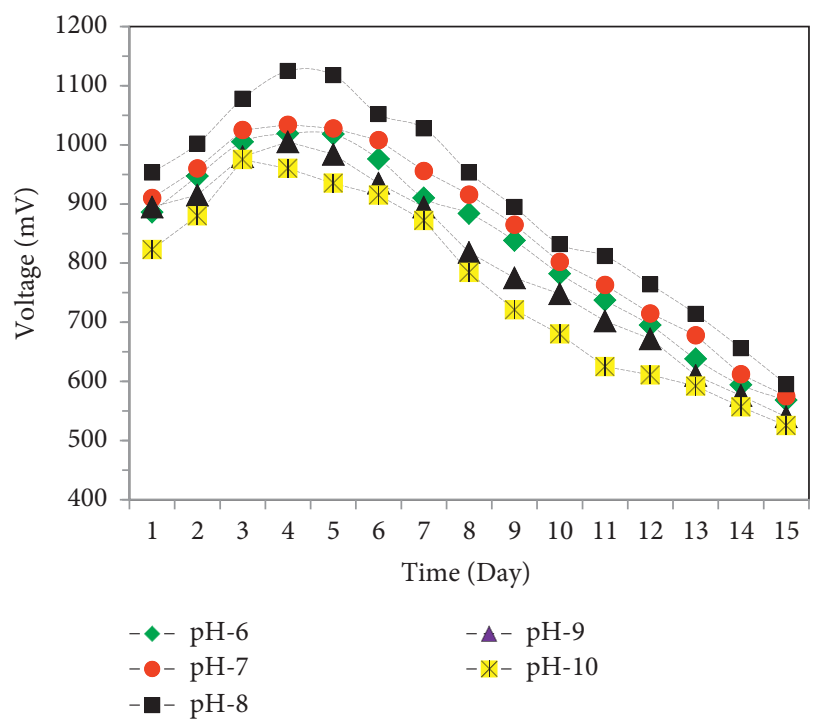

(a)

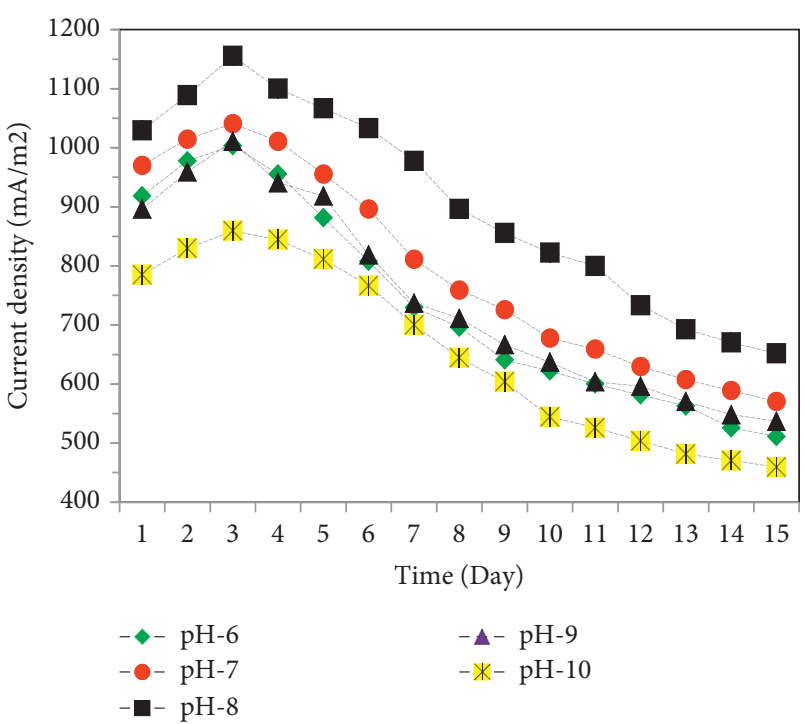

(b)

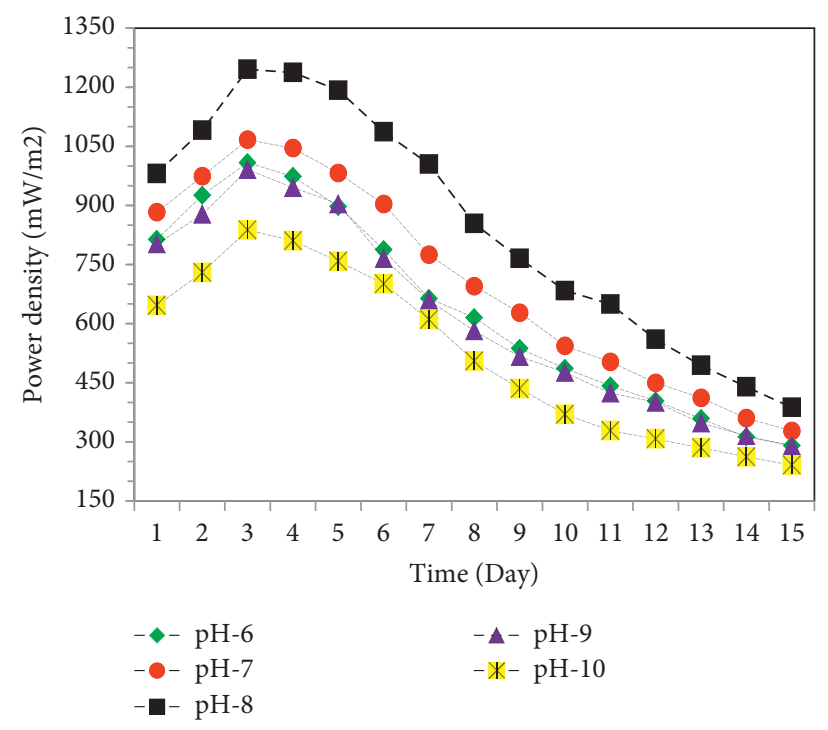

(c)

FIGURE 3: Effect of $\mathrm{pH}$ on the (a) generated voltage, (b) current density, and (c) power density by using municipal wastewater.

(in the form of voltage) was obtained from the MFC at $\mathrm{pH} 8$. The maximum value was recorded as $1132 \mathrm{mV}$. The effects of $\mathrm{pH}$ on current density and power density were also studied in this research. The results are shown in Figures 4(b) and 4(c). As seen from these figures, the extents of current density and power density increase in first several days of MFC operation for all experimented $\mathrm{pH}$ values and then gradually decrease. The maximum value of current density $\left(1288.9 \mathrm{~mA} \cdot \mathrm{m}^{-2}\right)$ and power density $\left(1459.02 \mathrm{~mW} \cdot \mathrm{m}^{-2}\right)$ was achieved at $\mathrm{pH} 8$ on day 4 . Therefore, the results demonstrated that the maximum output (in terms of voltage, current density, and power density) was achieved at $\mathrm{pH} 8$ at the current experimental conditions. The findings of the present study were much better than the reported results in the literature. Dhiraj et al. reported to employ graphite rods and $\mathrm{PbO}_{2}$ graphite as electrodes and river water as the electrolyte in MFC operation and obtained the maximum voltage, current density, and power density of $937 \mathrm{mV}$, $382 \mu \mathrm{A} \cdot \mathrm{cm}^{-2}$, and $86 \mu \mathrm{W} \cdot \mathrm{cm}^{-2}$, respectively [27]. Besides, Venkatamohan et al. used the hybrid electrode and Musi river water as the electrolyte and obtained a maximum current density of $62.23 \mathrm{~mA} \cdot \mathrm{m}^{-2}$ and power density of $15.56 \mathrm{~mW} \cdot \mathrm{m}^{-2}$ [28]. However, operating $\mathrm{pH}$ higher than 10 has been reported less suitable for bioelectricity harvesting, while near-neutral $\mathrm{pH}$ is reported to be favorable for electricity generation as well as COD removal $[22,29]$.

Apart from the bioelectricity generation, the COD removal and coulombic efficiency were also found to be higher at $\mathrm{pH}$ 8. In fifteen days of operation, the COD removal was $88 \%, 90 \%, 94 \%, 91 \%$, and $89 \%$ for initial electrolyte $\mathrm{pH}$ of $6,7,8,9$, and 10 , respectively. In the same manner, the coulombic efficiencies were found to be 


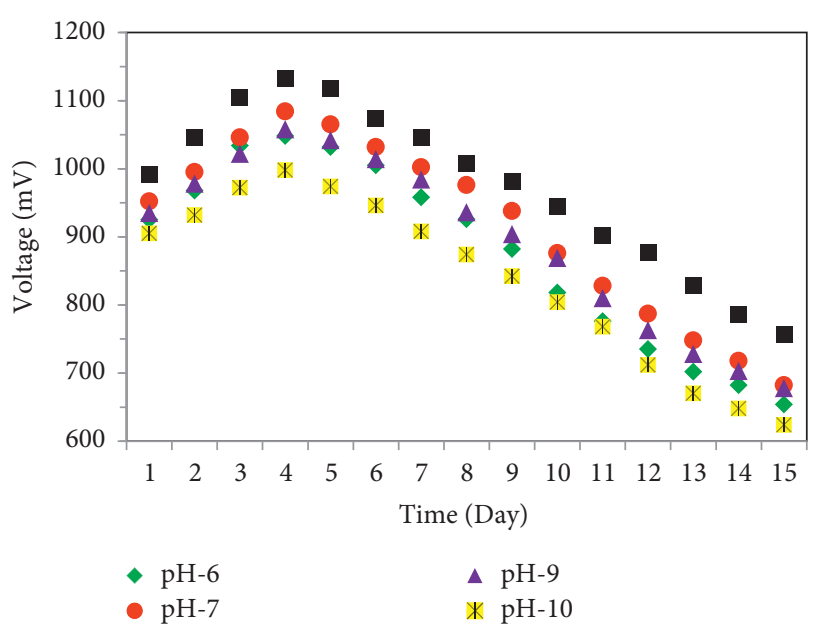

- $\mathrm{pH}-8$

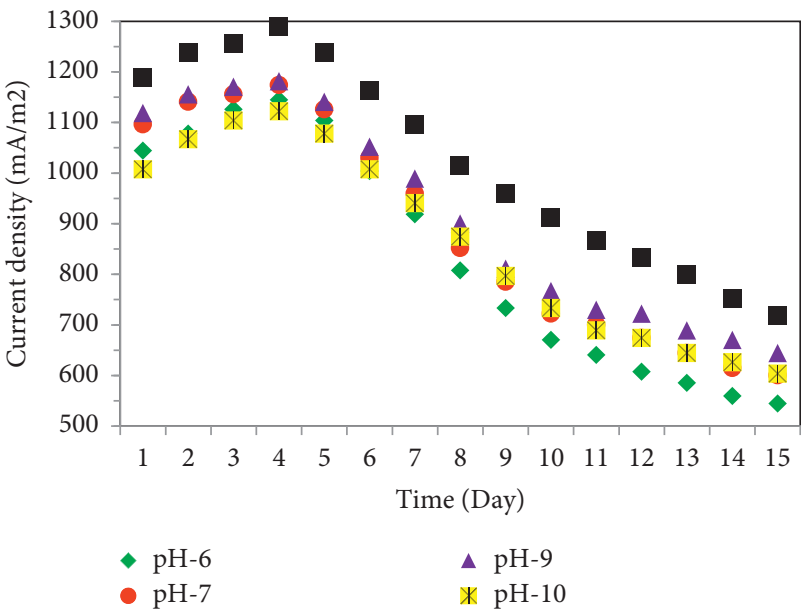

(b)

(a)

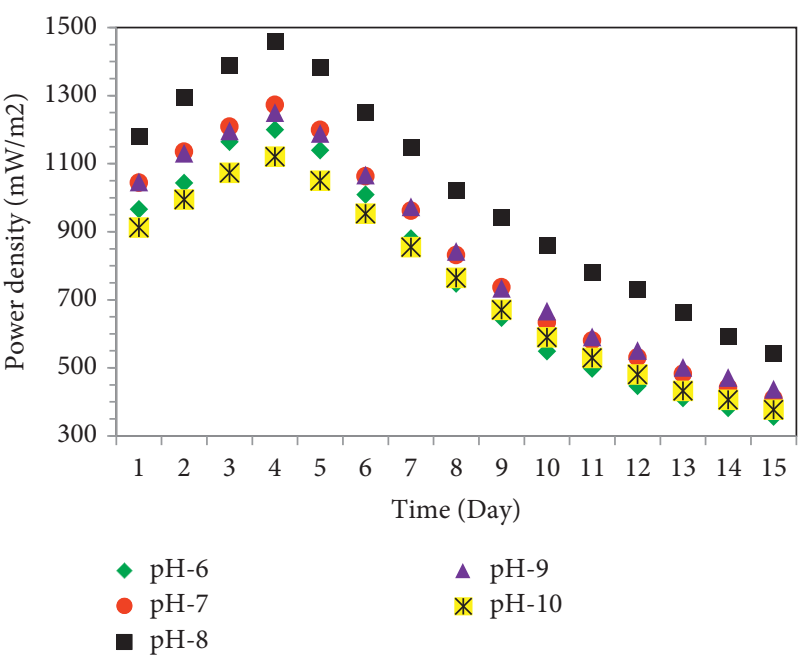

(c)

FIGURE 4: Effect of $\mathrm{pH}$ on the (a) generated voltage, (b) current density, and (c) power density by using biomass feed from Bhairab river water.

$32.85 \%, 36.6 \%, 41.7 \%, 37.4 \%$, and $35.7 \%$ for electrolyte $\mathrm{pH}$ of $6,7,8,9$, and 10 , respectively. The overall findings signify that the present setup of the MFC can be well used for bioelectricity generation as well as for microtreatment of wastewater.

\subsection{Effect of $p H$ Using Hospital Wastewater as the Electrolyte.} The final feedstock (wastewater) was collected from a drain of Jashore General Hospital. To examine the effect of $\mathrm{pH}$ on the performance of the microbial fuel cell, a series of experiments were performed by varying initial $\mathrm{pH}$ of the collected wastewater. The generated voltage and current were recorded for 15 days at a stretch, and current densities as well as power densities were analyzed. The results are depicted in Figures 5(a)-5(c). From these figures, it is clear that the voltage, current density, and power density increase at the initial stage (from day 1 to day 4 ) of the experiments and reach to the peak on day 4 . After four days of operation of the MFC, the extents of these efficiency factors (e.g., voltage, current density, and power density) start to decrease gradually. This trend is observed for all experimented $\mathrm{pH}$ values. In these experiments, the maximum values of voltage and current density were found to be $1016 \mathrm{mV}$ and $1007.41 \mathrm{~mA} \cdot \mathrm{m}^{-2}$, respectively. Unlike municipal wastewater and Bhairab river water, the highest values of both voltage and current density were achieved at $\mathrm{pH}$ 9. As shown in Figure 5(c), the maximum power density $\left(1023.53 \mathrm{~mW} \mathrm{~m}^{-2}\right)$ was found to be achieved on day 4 at $\mathrm{pH}$ 9. The extent of power density was much higher than the value reported in the literature where hospital wastewater and graphite were used as the electrolyte and electrode, respectively [30].

During the experiment, COD removal and CE were also determined. In fifteen days of operation, the COD removal was calculated to be $78 \%, 83 \%, 86 \%, 88 \%$, and $84 \%$ at wastewater initial $\mathrm{pH} 6,7,8,9$, and 10 , respectively. In addition to this, the coulombic efficiencies were determined to be $22.3 \%, 23.9 \%$, $28.7 \%, 31.9 \%$, and $26.1 \%$ at initial $\mathrm{pH} 6,7,8,9$, and 10 , 


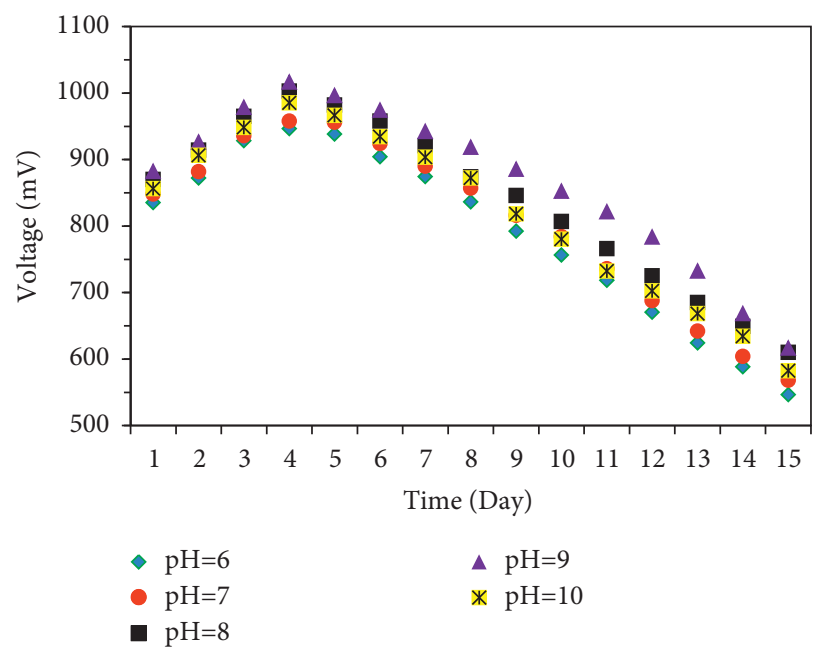

(a)

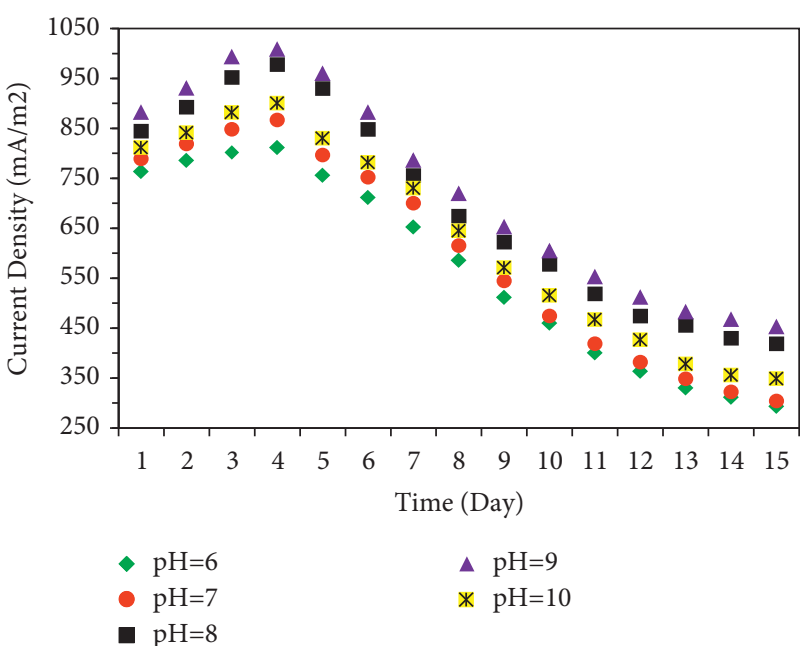

(b)

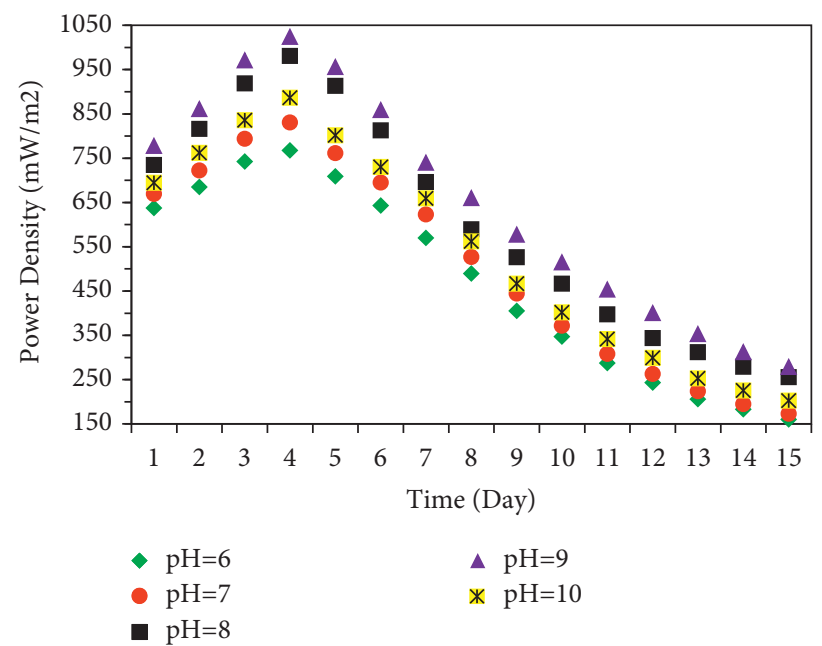

(c)

FIGURE 5: Effect of $\mathrm{pH}$ on the (a) generated voltage, (b) current density, and (c) power density by using hospital wastewater.

respectively. Therefore, the maximum COD removal (88\%) and $\mathrm{CE}(31.9 \%)$ were achieved at $\mathrm{pH} 9$ for hospital wastewater.

\section{Conclusion}

The present study successfully investigated the influence of $\mathrm{pH}$ of wastewater of two different sources and water of a local river and compared outputs of a fabricated microbial fuel cell in terms of voltage, current density, and power density. Initial $\mathrm{pH}$ of the feedstock was found to greatly affect the output of the MFC. The output increased in first several days of the operation and then decreased with the course of time. The maximum output (power density: $1459.02 \mathrm{~mW} \cdot \mathrm{m}^{-2}$, current density: $1288.9 \mathrm{~mA} \cdot \mathrm{m}^{-2}$, and voltage: $1132 \mathrm{mV}$ ) was found to occur for Bhairab river water as the feedstock at $\mathrm{pH}$ 8. The highest COD removal (94\%) and coulombic efficiency $(41.7 \%)$ were observed for the same electrolyte at $\mathrm{pH} 8$ too. The novelty of this research is twofold: utilization of the local biomass feedstock as the potential anolyte and considerably high extent of power density, COD removal, and CE of the constructed MFC. Although the harvested bioelectricity cannot be used in the automobile sector, modification in MFC design and process optimization can be investigated in future studies in pursuit of running electronic devices and other lowpower-intensive medical instruments.

\section{Data Availability}

All data generated through experiments and analyzed during this study are included within this article.

\section{Disclosure}

A preprint of this article also exists in a preprint platform of Research Square (DOI: 10.21203/rs.3.rs-151072/v1). This research was performed as part of the employment at Jashore University of Science and Technology.

\section{Conflicts of Interest}

The authors declare that they have no conflicts of interest. 


\section{References}

[1] T. Feng, W. Zhou, S. Wu et al., "Simulations of summertime fossil fuel $\mathrm{CO}_{2}$ in the Guanzhong basin, China," The Science of the Total Environment, vol. 624, no. 3, pp. 1163-1170, 2018.

[2] P. M. Gotovtsev and A. V. Dyakov, "Biotechnology and internet of things for green smart city application," in Proceedings of the 2016 IEEE 3rd World Forum on Internet of Things (WFIoT), pp. 542-546, Reston, VA, USA, December 2016.

[3] S. Rajeswari, S. Vidhya, R. Navanietha Krishnaraj et al., "Utilization of soak liquor in microbial fuel cell," Fuel, vol. 181, pp. 148-156, 2016.

[4] G. Harshitha, A. Sahoo, and R. Sethy, "Bioelectricity generation from different biomass feed at anode chamber and to study process parameters in microbial fuel cells," Biocatalysis and Agricultural Biotechnology, vol. 20, Article ID 101191, 2019.

[5] S. Li, C. Cheng, and A. Thomas, "Carbon-based microbialfuel-cell electrodes: from conductive supports to active catalysts," Advanced Materials, vol. 29, no. 8, Article ID 1602547, 2017.

[6] R. A. Rozendal, H. V. M. Hamelers, and C. J. N. Buisman, "Effects of membrane cation transport on $\mathrm{pH}$ and microbial fuel cell performance," Environmental Science \& Technology, vol. 40, no. 17, pp. 5206-5211, 2006.

[7] H. J. Porwal, A. V. Mane, and S. G. Velhal, "Biodegradation of dairy effluent by using microbial isolates obtained from activated sludge," Water Resources and Industry, vol. 9, pp. 1-15, 2015.

[8] V. Sawasdee and N. Pisutpaisal, "Simultaneous pollution treatment and electricity generation of tannery wastewater in air-cathode single chamber MFC," International Journal of Hydrogen Energy, vol. 41, no. 35, pp. 15632-15637, 2016.

[9] L. Damiano, J. R. Jambeck, and D. B. Ringelberg, "Municipal solid waste landfill leachate treatment and electricity production using microbial fuel cells," Applied Biochemistry and Biotechnology, vol. 173, no. 2, pp. 472-485, 2014.

[10] G. E. Oyiwona, J. C. Ogbonna, C. U. Anyanwu, and S. Okabe, "Electricity generation potential of poultry droppings wastewater in microbial fuel cell using rice husk charcoal electrodes," Bioresources and Bioprocessing, vol. 5, no. 1, 2018.

[11] D. Hidalgo, T. Tommasi, K. Velayutham, and B. Ruggeri, "Long term testing of microbial fuel cells: comparison of different anode materials," Bioresource Technology, vol. 219, pp. 37-44, 2016.

[12] Y. Asensio, C. M. Fernandez-Marchante, J. Lobato, P. Cañizares, and M. A. Rodrigo, "Influence of the fuel and dosage on the performance of double-compartment microbial fuel cells," Water Research, vol. 99, pp. 16-23, 2016.

[13] M. Ghasemi, E. Halakoo, M. Sedighi, J. Alam, and M. Sadeqzadeh, "Performance comparison of three common proton exchange membranes for sustainable bioenergy production in microbial fuel cell," Procedia CIRP, vol. 26, pp. 162-166, 2015.

[14] S. Sevda and T. R. Sreekrishnan, "Effect of salt concentration and mediators in salt bridge microbial fuel cell for electricity generation from synthetic wastewater," Journal of Environmental Science and Health, Part A, vol. 47, no. 6, pp. 878-886, 2012.

[15] A. Gonzalez del Campo, J. F. Perez, P. Cañizares, M. A. Rodrigo, F. J. Fernandez, and J. Lobato, "Study of a photosynthetic MFC for energy recovery from synthetic industrial fruit juice wastewater," International Journal of $\mathrm{Hy}$ drogen Energy, vol. 39, no. 36, pp. 21828-21836, 2014.
[16] S. W. Hong, I. S. Chang, Y. S. Choi, and T. H. Chung, "Experimental evaluation of influential factors for electricity harvesting from sediment using microbial fuel cell," Bioresource Technology, vol. 100, no. 12, pp. 3029-3035, 2009.

[17] M. A. Halim, M. O. Rahman, I. A. Eti, N. R. Shefa, M. Ibrahim, and M. J. Alam, "Electricity generation in different cell connections with optimized anodic materials in microbial fuel cells," Energy Sources, Part A: Recovery, Utilization, and Environmental Effects, pp. 1-13, 2020.

[18] A. G. Capodaglio, D. Molognoni, E. Dallago et al., "Microbial fuel cells for direct electrical energy recovery from urban wastewaters," Science World Journal, vol. 2013, pp. 1-8, Article ID 634738, 2013.

[19] G. S. Jadhav and M. M. Ghangrekar, "Performance of microbial fuel cell subjected to variation in $\mathrm{pH}$, temperature, external load and substrate concentration," Bioresource Technology, vol. 100, no. 2, pp. 717-723, 2009.

[20] K. Scott, I. Cotlarciuc, I. Head et al., "Fuel cell power generation from marine sediments: investigation of cathode materials," Journal of Chemical Technology \& Biotechnology, vol. 83, no. 9, pp. 1244-1254, 2008.

[21] M. A. Halim, M. O. Rahman, M. Ibrahim, R. Kundu, and B. Biswas, "Study of the effect of $\mathrm{pH}$ on the performance of microbial fuel cell for generation of bioelectricity," Research Square, 2021.

[22] G.-C. Gil, I.-S. Chang, B. H. Kim et al., "Operational parameters affecting the performannce of a mediator-less microbial fuel cell," Biosensors and Bioelectronics, vol. 18, no. 4, pp. 327-334, 2003.

[23] S. M. Abhilasha, "Inoculum selection to enhance performance of a microbial fuel cell for electricity generation during wastewater treatment," Environmental Technology, vol. 34, pp. 1957-1964, 2013.

[24] L. Zhang, X. Zhu, J. Li, Q. Liao, and D. Ye, "Biofilm formation and electricity generation of a microbial fuel cell started up under different external resistances," Journal of Power Sources, vol. 196, no. 15, pp. 6029-6035, 2011.

[25] S. Omprakash, "Sustainable and clean treatment of industrial wastewater with microbial fuel cell," Engineering, vol. 4, Article ID 100053, 2019.

[26] S. Zinadini, A. A. Zinatizadeh, M. Rahimi, V. Vatanpour, and Z. Rahimi, "High power generation and COD removal in a microbial fuel cell operated by a novel sulfonated PES/PES blend proton exchange membrane," Energy, vol. 125, pp. 427-438, 2017.

[27] C. Dhiraj, J. Vijay, K. D. Harish, and K. Datta, "Influence of microbial fuel cell employed with porous anode on the voltage generation, COD, chloride content and total dissolved solids," Water Science and Technology, vol. 82, no. 7, pp. 1285-1295, 2020.

[28] S. Venkatamohan, S. Srikanth, S. Veerraghuvulu, G. Mohanakrishna, A. Kirankumar, and P. N. Sarma, "Evaluation of the potential of various aquatic eco-systems in harnessing bioelectricity through benthic fuel cell: effect of electrode assembly and water characteristics," Bioresource Technology, vol. 100, no. 7, pp. 2240-2246, 2009.

[29] M. Behera, P. S. Jana, T. T. More, and M. M. Ghangrekar, "Rice mill wastewater treatment in microbial fuel cells fabricated using proton exchange membrane and earthen pot at different pH," Bioelectrochemistry, vol. 79, no. 2, pp. 228-233, 2010.

[30] P. Aelterman, K. Rabaey, P. Clauwaert, and W. Verstraete, "Microbial fuel cells for wastewater treatment," Water Science and Technology, vol. 54, no. 8, pp. 9-15, 2006. 